\title{
Effects of Climate Warming, North Atlantic Oscillation, and EI Niño-Southern Oscillation on Thermal Conditions and Plankton Dynamics in Northern Hemispheric Lakes
}

\author{
Dieter Gerten ${ }^{1,2}$ and Rita Adrian*, \\ ${ }^{1}$ Leibniz-Institut für Gewässerökologie und Binnenfischerei, Müggelseedamm 301, \\ D-12587 Berlin, Germany; ${ }^{2}$ Current address: Potsdam-Institut für Klimafolgenforschung, \\ Telegrafenberg C4, D-14412 Potsdam, Germany
}

Received November 8, 2001; Revised January 17, 2002; Accepted January 23, 2002; Published March 8 , 2002

Impacts of climate warming on freshwater ecosystems have been documented recently for a variety of sites around the globe. Here we provide a review of studies that report long-term (multidecadal) effects of warming trends on thermal properties and plankton dynamics in northern hemispheric lakes. We show that higher lake temperatures, shorter periods with ice cover, and shorter stagnation periods were common trends for lakes across the hemisphere in response to the warmer conditions. Only for shallow dimictic lakes was it observed that deepwater temperatures decreased. Moreover, it became evident that phytoplankton dynamics and primary productivity altered in conjunction with changes in lake physics. Algal spring blooms developed early and were more pronounced in several European lakes after mild winters with short ice cover periods, and primary productivity increased in North American lakes. Effects of elevated temperatures on zooplankton communities were seen in an early development of various species and groups, as is documented for cladocerans, copepods, and rotifers in European lakes. Furthermore, thermophile species reached higher abundance in warmer years.

Obviously, the nature of responses is species specific, and depends on the detailed seasonal patterning of warming. Complex responses such as effects propagating across trophic levels are likely, indicating that observed climateecosystem relationships are not generally applicable. Nonetheless, the picture emerges that climate-driven changes in freshwater ecosystems may be synchronised to a certain extent among lakes even over great distances if climatic influences are not masked by anthropogenic impacts or differences in lake morphology. Macro-scale climatic fluctuations - such as the North Atlantic Oscillation or the EI Niño-Southern Oscillation - were identified as the most important candidates responsible for such coherence, with the former predominating in Europe and the latter in North America. We emphasise, however, that the driving mechanisms and the future behaviour of these oscillations are 
rather uncertain, which complicates extrapolation of observed effects into the future. Thus, it is necessary to quantify the most important climate-ecosystem relationships in models of appropriate complexity. Such models will help elucidate the multiple pathways climate affects freshwater ecosystems, and will indicate possible adverse effects of a warmer future climate.

KEY WORDS: climate change, freshwater ecosystems, North Atlantic Oscillation, EI Niño-Southern Oscillation, lake ice, long-term, phytoplankton, zooplankton, large-scale synchronization

DOMAINS: freshwater systems, ecosystems and communities, atmospheric systems, ecosystems management

\section{INTRODUCTION}

Weather and climate regulate physical, chemical, and biological processes in freshwater ecosystems at all time scales[1]. The physical features of lakes are most directly influenced by climate, as they are controlled by solar radiation, air temperature, and wind velocity[2]. Effects of ambient meteorological conditions on the biota of lakes are also well described. For example, the timing, composition, and intensity of the phytoplankton spring bloom in temperate lakes are tightly coupled to solar radiation, water temperature, and wind-induced turbulence[3,4]. Temperature, in particular, is of paramount importance for virtually all physiological and lifehistory parameters of aquatic organisms[2,5,6].

Over the long term, climate is considered the prime factor imparting variability to thermal conditions and biological processes in lakes, if pervasive human influences are absent[7]. In view of anticipated global warming (see Box 1), aquatic ecologists have made great effort during the past 10-15 years in exploring possible changes in freshwater ecosystems induced by recent warming trends or extreme weather conditions, or both. Current warming trends largely match projections of a warmer future climate (Box 1). Consequently, relationships established for recent decades are particularly valuable, because they indicate - at least qualitatively — the likely nature of ecological changes in the future[8]. Most of the studies were based on analyses of synchronous long-term records of ecological and limnological variables, respectively, which were derived from systematic ecosystem monitoring at a variety of sites particularly in North America and Europe. Some investigations were imbedded in international research programs, which had been founded to address explicitly the long-term dynamics of relevant variables in (aquatic) ecosystems (see, in particular, the Response of European Freshwater Lakes to Environmental and Climatic Change (REFLECT) project[9], the Long Term Ecological Research (LTER) programs[10], and the Freshwater Biological Association[11]).

Here we provide a review of observed decadal-scale effects of climate warming on lakes in the Northern Hemisphere. For the sake of brevity, we consider only impacts that were not fully covered by previous reviews, focussing primarily on impacts on thermal conditions and plankton dynamics. Excellent overviews already exist on the interaction of effects of climate warming with other anthropogenic impacts (e.g., activities in the catchments and their influences on lake chemistry, water pollution, overexploitation of resources[12,13,14,15,16,17,18,19,20], acid rain, and increased UV-B radiation[21]). We also do not discuss possible changes in biodiversity and biogeographical distributions of species, nor ecological invasions or species extinctions, which may happen in response to climatic change[22,23]. Climate warming effects on fish will not be considered here as well, since information on this topic has been published recently[12,24,25,26,27]. 
Box 1 - Chimate Warming. There seems little doubt that global climate warming is in progress, as the Earth's mean surface temperature increased by about $0.6 \pm 0.2^{\circ} \mathrm{C}$ in the course of the $20^{\text {th }}$ Century, including a maximum warming rate since around 1976[144,145]. The five warmest years in the Northern Hemisphere since at least 1400 A.D. all were recorded in the $1990 \mathrm{~s}[146,147]$. Much of this temperature increase is ascribed to the increasing long-term trends in anthropogenic emissions of greenhouse gases such as carbon dioxide and methane[145].

General Circulation Models project that the warming is likely to continue in the future. Global mean temperature is expected to increase by $1.4-5.8^{\circ} \mathrm{C}$ by the end of the current century, depending on the model and the underlying emission scenario[145]. The warming, however, will likely be accompanied by changes in local climate (temperature, precipitation, storm frequency, etc.), the magnitude and nature of which are still rather uncertain.

One of our objectives is to summarise effects of the two most dominant large-scale atmospheric circulation patterns controlling climate in large parts of the Northern Hemisphere: the North Atlantic Oscillation (NAO) and the El Niño-Southern Oscillation (ENSO) (Box 2). We aim to demonstrate that these circulation phenomena play an important role in synchronising changes among lake ecosystems over great distances, if climatic influences are not masked by anthropogenic impacts or differences in lake morphology.

BOX 2 - NORTH ATLANTIC OSCILLATION AND EL Niño-SOUTHERN OSCILLATION. A substantial fraction of the most recent warming in the Northern hemisphere was accounted for by a marked positive phase of a natural atmospheric circulation mode known as North Atlantic Oscillation (NAO) $[145,148]$. The $\mathrm{NAO}$ is a prime source of interannual and interdecadal climate variability in vast extratropical regions ranging from the eastern seaboard of the U.S. across the Atlantic up to Central Asia and north-western Africa[149,150,151]. Although the NAO is evident throughout the year, it is most pronounced during winter, explaining about one third of Northern Hemispheric temperature variability throughout December-March[122].

The NAO actually refers to a seesaw in air pressure differences between the subpolar Icelandic low and the subtropical Azores high, the two dominant centers of action over the North Atlantic[152,153]. Winters characterised by high air pressure gradients alternate at quasi-decadal intervals (6-10 years) with winters dominated by low gradients[154,155]. The NAO is commonly expressed in terms of an NAO index, which refers to the difference in sea level pressure anomalies between climate stations amidst the Azores high and the Icelandic low[116,156]; Hurrell's index is available via Internet[157]. High differences (indicated by a positive NAO index) usually produce a pronounced westerly wind component and predominating zonal circulation over the North Atlantic, yielding mild and rainy winters in West and North Europe, and cold winters in eastern North America. In contrast, low pressure gradients (negative index) cause a weaker and more meridional circulation pattern, likely resulting in cold winters over Europe, and mild conditions in parts of North America[154]. A high NAO phase dominated most of the winters during the most recent decade. 
The rather simple NAO index can be easily applied to establish relationships between large-scale climatic variation and, for instance, ecological variables. The majority of NAO impact studies is based on Hurrell's index, which captures the pressure gradient between Stykkishólmur (Iceland) and Ponta Delgada (Azores)[116]. The NAO was identified recently as a main factor affecting ecological processes in both terrestrial and aquatic environments situated within the sphere of its influence[141].

The El Niño-Southern Oscillation (ENSO) is a recurring atmosphericoceanic phenomenon taking place every few years across the tropical Pacific $[158,159]$. The most important manifestation of that oscillation are the warm ENSO events (El Niños), which are characterised by above-normal sea surface temperatures in the central and eastern equatorial Pacific during a period lasting for several months[160]. Measures of the ENSO are, for example, the NINO3 index[161] that refers to the sea surface temperature anomalies in the tropical Pacific, or the Southern Oscillation index[162], which is defined as the air pressure difference between Tahiti and Darwin (Australia).

ENSO is the most important driving mechanism of seasonal to interannual climate variability not only over tropical but also over vast extratropical regions, and the warming influence of El Niño on global temperature is now well attested[145,163]. Since the late 1970s, the warm ENSO state predominates, and the most dramatic El Niño events of the past century occurred in 1982 and 1983 and in 1997 and 1998[164,165]. These events were characterised, for example, by more zonal flow than normal and an eastward displacement of the Pacific Jet Stream, which resulted in very mild winters over much of northern and central North America, while precipitation patterns changed spatially inconsistently[107]. It should be borne in mind that the ENSO explains only a portion of winter temperature variability in North America[166,167], as regional phenomena and teleconnections with other circulation patterns such as the NAO exist[103,106,168]. ENSO influences are relatively weak over Europe[169,170].

Biological responses to El Niño episodes cover a wide range of ecosystems and taxa, including, for example, fisheries declines[171,172], range expansions of marine species[173,174], variations in discharge and associated changes in river ecology[175], or coral bleaching[164]. The signature of ecological ENSO impacts, however, is strongly regional[176].

\section{EFFECTS OF CLIMATE WARMING ON LAKE PHYSICS}

The physical properties of water bodies are of utmost importance for most ecological processes in freshwater systems[2]. Ice formation, for instance, has a substantial influence on the underwater light, temperature, and turbulence regime[4,28]. Thus, changes in the duration of ice cover periods may induce significant changes in the inocula of phytoplankton, which in turn may affect the seasonal succession of plankton. Thermal stratification may also affect considerably the structure and composition of plankton assemblages. For example, in Rostherne Mere (U.K.), Scenedesmus predominated in the phytoplankton community in years when stratification was unusually stable while Oscillatoria predominated in years with frequent mixing[29]. The length of the stagnation period may furthermore affect nutrient availability. For small dimictic 
Heiligensee (Berlin, Germany), it was found that more nutrients accumulated in the hypolimnion in years with early stratification onset[30]. Here we provide an overview of long-term changes in lake physics (water temperature, stratification behaviour, ice conditions) that were observed recently for lakes around the Northern Hemisphere.

\section{Effects on Thermal Properties}

A number of climate impact studies demonstrated pronounced effects of recent warming tendencies on thermal habitats of freshwater ecosystems. Water temperatures usually increased in parallel with higher air temperatures. The first report of this phenomenon[14] documented that mean water temperatures of boreal lakes in northwestern Ontario increased by $\approx 2{ }^{\circ} \mathrm{C}$ during the period 1969-1988. Subsequent studies provided further evidence that water temperatures of numerous lakes in the Northern Hemisphere increased significantly during the most recent decades (namely in winter/spring[30,31,32], summer[33,34,35,36], and autumn[37]).

Hypolimnetic water temperatures of thermally stratified lakes responded less consistently to climate warming trends, mainly because climate effects were modulated decisively by lake depth and morphology. Deep-water temperatures increased little or not at all at higher air temperatures[32,34,38]. Yet, accumulative multiannual warming is likely to occur in very deep, oligomictic lakes that do not fully circulate each winter[39,40]. The hypolimnia of shallow lakes tended to become colder in years with warm weather, probably as a consequence of earlier stratification at low lake temperatures[32].

The advanced onset of thermal stratification in lakes in response to rising air temperatures is documented by several studies[30,33,34]. There are also indications that the mixis regime of lakes was altered in warm years. Polymictic lakes stratified more permanently[41], and dimictic lakes were predicted to become more monomictic due to the lack of inverse stratification in icefree winters[42,43].

Additionally, it was observed that metalimnia became sharper in warm years[33]. Moreover, mixing depths increased in small but not in large lakes in warm, bright summers. The main reason for this discrepancy is that mixing depth in large lakes $\left(>\approx 5 \mathrm{~km}^{2}\right)$ is controlled primarily by aspects of wind exposure, while in small water bodies, water clarity, cloud cover, and solar penetration are important[34,44,45]. Water clarity, in turn, will decrease, if fish and phytoplankton abundance[46] or DOC levels are high[47].

\section{Effects on Ice Conditions}

Historical (decadal to centennial) records of ice freeze- and break-up dates are available for a variety of sites in temperate latitudes of the Northern hemisphere[48]. Analysis of these time series provides valuable information about lake responses to short-term and, particularly, longterm variations in the winter climate. A variety of studies documented that ice cover periods of lakes have shortened remarkably during the past decades in Wisconsin[49,50,51], western Ontario[14], New Hampshire[52], Siberia[53], Japan[54], Finland[55], Switzerland[56], Germany[57], and Sweden[58].

Specifically, significant changes toward earlier ice break-up dates happened both around 1890 and around 1980 at Lake Mendota (Wisconsin)[49]. For Müggelsee (Berlin, Germany), a $1{ }^{\circ} \mathrm{C}$ increase in winter air temperature resulted in a reduction of ice coverage by about 17 days[59]. This reduction in ice coverage is similar to that recorded for North American lakes (Lake Mendota, 12.7 days; Grand Traverse Bay, Lake Michigan, 15.5 days [50]). Yet ice thickness, lake size, and latitudinal position modify these figures[60]. In addition to earlier breakup dates, later freeze-up dates were observed for Lake Suwa (Japan)[54] and for Mirror Lake (New Hampshire)[52]. Furthermore, the ice-free season is expected to extend dramatically in Arctic lakes such as Toolik Lake (Alaska)[61] while in lower latitudes, ice formation does not 
occur at all in extremely mild winters[43,50,59]. Overall, ice duration on lakes and rivers decreased consistently across the Northern Hemisphere during the past 150 years[62].

\section{EFFECTS OF CLIMATE WARMING ON LIMNETIC PLANKTON COMMUNITIES}

Climatic conditions cause interannual and interdecadal variability in freshwater plankton communities[7]. Although physical features, anthropogenic impacts, and nutrient availability may be more important drivers for phytoplankton growth and abundance than direct climatic influences[60,63], climate exerts numerous indirect influences on aquatic food webs. Thus, global climate warming is anticipated to induce a number of interrelated effects across the trophic cascade in lakes around the globe[12]. Generally, it is expected that productivity may increase at all food web levels. In other words, effects of climate warming (e.g., increases in primary production, zooplankton biomass, and fish yields) will superficially resemble eutrophication[64]. In the following section, we discuss recent studies that document climate-related changes in freshwater plankton communities in the Northern Hemisphere.

\section{Effects on Phytoplankton and Primary Production}

Climatically driven changes in phytoplankton abundance first became obvious in European freshwaters after a series of very mild winters in the late 1980s and early 1990s. Besides higher chlorophyll $a$ concentrations during the winter season in small Heiligensee, the development of the spring bloom started about 1 month earlier in that lake. This was probably a consequence of shorter ice covers and, thus, better light conditions[30]. Additionally, the algal composition shifted toward a dominance of cyanophytes, as earlier stratification and earlier nutrient limitation prevented diatoms from becoming dominant[30,65].

In some other lakes, the phytoplankton composition in spring was dominated by diatoms after mild winters, and the spring bloom occurred early and was more pronounced (Plußsee (northern Germany)[66]; Müggelsee[57]; Lake Erken (southern Sweden)[58]). These changes also stemmed from the shortening of ice cover periods in mild winters, which favoured diatom growth owing to enhanced turbulent mixing and better light conditions. Furthermore, phytoplankton biomass in summer in Lake Erken was related to the timing of ice break-up[67]. The authors speculated that the earlier spring bloom after mild winters resulted in a longer mineralisation time, which in turn led to higher nutrient availability for the summer bloom.

Moreover, it became apparent that annual primary production in both Lake Tahoe (California) and Castle Lake (California) were related strongly to ambient weather conditions[68]. Primary productivity in the former was mainly determined by the maximal depth of spring mixing, which affected the quantity of nutrients returned from deep waters to the euphotic zone. On the contrary, annual productivity in Castle Lake was related to the amount of winter snowfall and spring precipitation. For example, productivity was low in years with much snowfall, which delayed ice break-up and the onset of the growing season. In addition, high amounts of subsequent spring rain led to the washout of substances involved in summer production. These processes affected particularly the hypolimnetic productivity in summer, whereas epilimnetic productivity in late summer was controlled by interactions on higher trophic levels[69]. Similarly, large Canadian Shield lakes had higher annual rates of primary production than small lakes, owing to the longer ice-free period and the deeper mixed layer of the former[70]. Long-term changes in primary productivity are, to our knowledge, not documented for lakes outside of North America, but the observed increases in vernal phytoplankton biomass in several European lakes indicates similar changes there[30,57,58,66]. 


\section{Effects on Zooplankton}

Similarly to phytoplankton, zooplankton populations (rotifers and cladocerans) reached their spring maximum earlier after mild winters in some central European lakes[57,66,71,72]. The main reasons for these changes were either the climate-induced rise in algal availability, or warmer conditions in early spring, which led to early development of zooplankton. Magnitudes of zooplankton peaks, however, usually were independent of winter conditions[57,72], except for Daphnia in Lake Constance[73] (see below). Additionally, the dominance of colonial diatoms in Esthwaite Water (U.K.) in mild, windy winters resulted in high abundance of Eudiaptomus gracilis, while D. hyalina were more abundant in cold winters[74].

Furthermore, the clear-water phase - a typical drop in algal biomass in late spring in temperate meso- and eutrophic lakes - occurred about 2 weeks earlier in several lakes when water temperatures were above-normal during winter and spring (Plußsee[66], Lake Constance[71], Müggelsee[72]). Higher water temperature led to an earlier peak in Daphnia abundance, whose grazing pressure suppressed the preceding phytoplankton bloom. Even the timing of the decline of Daphnia abundance in July in Lake Constance was correlated with meteorological conditions in winter[71]. Contrarily, the occurrence and duration of the midsummer decline of D. galeata in shallow polymictic Bautzen Reservoir (Germany) was related to warming events in spring and summer rather than in winter[75]. Specifically, the spring warming triggered an early and high abundance of daphnids, which led to high mortality rates due to aging and low reproduction during the resulting clear-water phase. The warming in early summer caused additional mortality by early growth and predation of planktivorous young-of-the-year fish.

Impacts of meteorological conditions in early summer on zooplankton communities were also described for Lake Windermere (U.K.), where zooplankton populations may be more effectively controlled by weather than by abundance of planktivorous fish[76]. In fact, biomass of crustacean zooplankton was high in summers following warm Junes. When the lake became stratified in June already, population of edible algae developed earlier than in other years. As a consequence, the algal population developed too early to match the zooplankton population, which thus became food limited. Interestingly, these processes were also correlated significantly with year-to-year variations in the northerliness of the Gulf Stream[77,78].

Higher spring biomass of Daphnia in response to climatic conditions was observed for Lake Constance as well. Other than in England, however, this phenomenon was coupled to high water temperatures in early spring, which led to a reproductive success of the zooplankton[73]. Furthermore, elevated temperatures in late spring and summer led to a prolonged active phase of several copepod species in Müggelsee. That is, the animals emerged early from diapause in spring and entered diapause somewhat later in autumn[79]. In fact, these temporal shifts in seasonal phenologies were induced primarily by the higher water temperatures in late spring while effects of mid-summer heat waves were minor[35]. Thus, other than parthenogenetically reproducing cladocerans, copepods with their rather complex and prolonged annual life cycle are likely to show time-lagged responses to warming events.

\section{Species-Specific Responses}

Although many studies revealed climate effects at the level of functional or taxonomic plankton groups, it is most likely that the response of aquatic organisms varies at the species level. For instance, changes in the overwintering success of zooplankton in response to an autumnal warming trend differed among species[80]. Moreover, it was observed that zooplankton species in Heiligensee shifted from the large-bodied $D$. galeata to small D. cucullata in response to changes in the phytoplankton composition, which in turn had been induced by mild winters[65]. This observation is in agreement with that of Moore et al.[81], who found that high water 
temperatures caused reductions in body size of zooplankton populations. These shifts were mediated both directly and indirectly by other changes in the community, such as increased abundance of cyanobacteria at higher temperatures. In addition, abundance of Cyclops vicinus increased in Heiligensee due to the higher food availability in mild winters while $C$. kolensis decreased as a consequence of higher predation by $C$. vicinus [82].

Responses of cyclopoid copepods to warmer summer seasons also were clearly speciesspecific since only the most thermophile species exhibited higher peak abundance in those years, while Acanthocyclops robustus, a species adapted to a broad temperature range, was rather insensitive to the warming[35,79]. Moreover, the changes in the copepods' population dynamics depended on the detailed seasonal patterning of the warming, as they responded to warming events at certain times within the summer season only. For example, Thermocyclops oithonoides was influenced primarily by a warming in May, whereas Mesocyclops leuckarti was affected significantly by heat waves in mid-summer[35]. Laboratory experiments[81,83,84] suggest that secondary productivity of certain zooplankton species may have increased in response to climate warming, but long-term records to check that hypothesis are, to our knowledge, not available.

It is important to recognise that climate changes are likely to generate complex, and possibly time-lagged, direct and indirect responses in the entire food web $[85,86,87,88]$, and these responses are often nonlinear [89]. Moreover, future environments may include novel combinations of (climatic) variables not encountered in the data used to analyse the present relationships. Extrapolations of the latter consequently must be done carefully[87]. Nonetheless, there is no doubt that temperature-sensitive aquatic organisms act as harbingers of climate warming[90]. This indicator function of single species in ecosystems undergoing climate change is well recognised in terrestrial ecology (e.g., breeding phenology of birds[91], tree phenology[92], insect abundance[93]). It is, however, much less well developed in plankton ecology (but see[65,71,82]).

Overall, long-term studies ultimately suggest that the typical seasonal succession in lakes[94] is currently advancing in many meso- and eutrophic lakes in temperate latitudesnamely, the seasonal course of water temperature, ice break-up and stratification onset, the phytoplankton spring bloom, the clear-water phase, and the phenology of sensitive plankton species. This phenomenon agrees with observations for terrestrial environments where species are responding to the recent warming trends by advancing the date of their growth, reproduction, or migration[91,95,96,97].

\section{LARGE-SCALE SYNCHRONISATIONS: THE ROLE OF THE NAO AND THE ENSO}

Most climate impact studies cited herein report warming effects on single lakes. Yet, some studies provide strong evidence for a simultaneous response of multiple lakes at regional or even supraregional scales (see Fig. 1). These interlake synchronies usually are brought about by spatially coherent variation in climatic factors such as air temperature, precipitation, high-altitude cloud cover, and geostrophic wind velocity[31,36,98,99,100,101,102].

Therefore, aquatic ecologists should be alert to the possibility that changes in lake ecosystems may be synchronised by macroscale climatic fluctuations such as the NAO and the ENSO. In fact, the recent positive phase of the NAO contributed significantly to the elevated winter and spring surface water temperatures in lakes across Europe[31,32,71,74]. Moreover, the observed advancement in the ice break-up of lakes was controlled quasi-simultaneously by the NAO in a vast area covering, at least, southern Sweden[58], north-eastern Germany[72], Switzerland[103], and even Lake Baikal (Siberia)[53]. The NAO also affected plankton dynamics in several European lakes (Figs. 1, 2). The NAO-related early ice break-up (or the total lack of an 


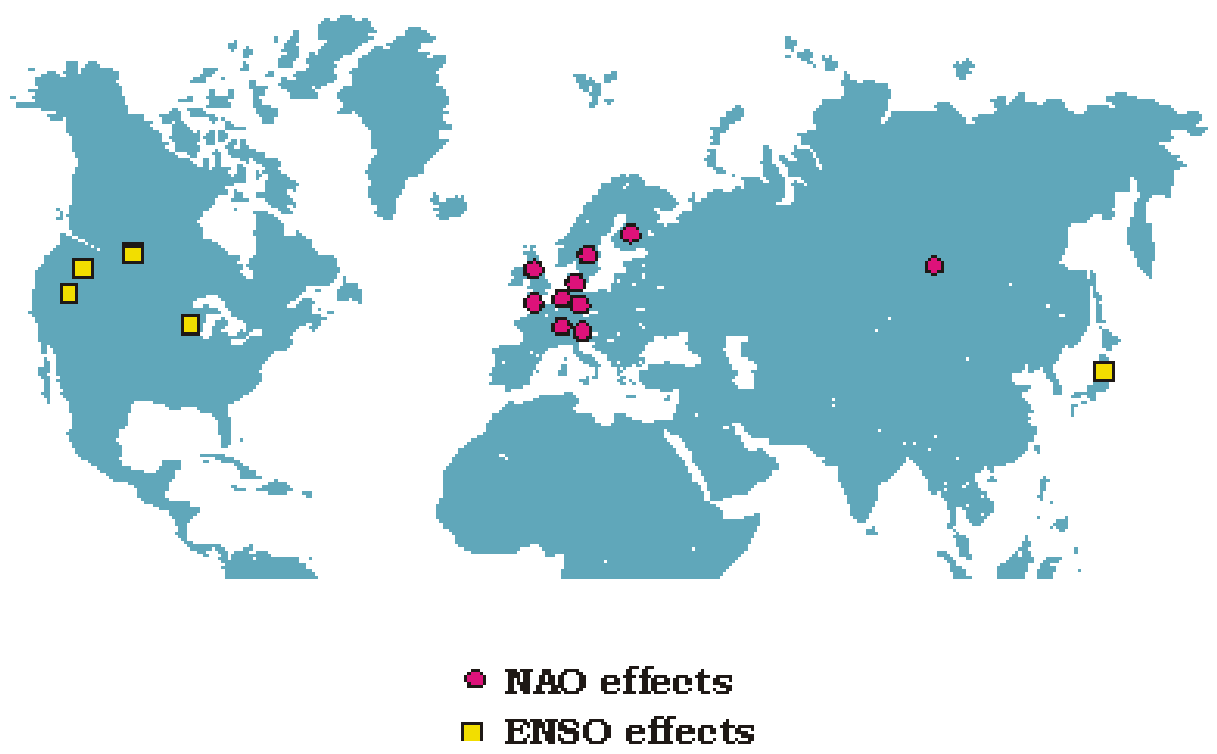

FIGURE 1. Locations of lakes in the Northern Hemisphere that were affected by either the NAO (red symbols) or the ENSO (yellow symbols). See text for references and processes involved.

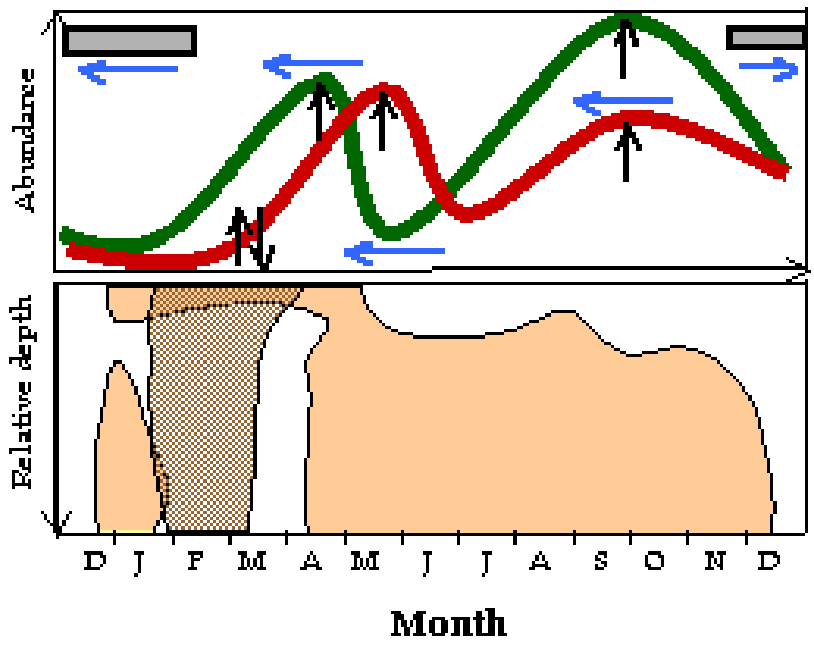

FIGURE 2. Schematic representation of warming impacts on freshwater ecosystems in temperate latitudes, based on long-term observations for a variety of lakes in Europe (see text for references). The upper panel illustrates effects on the seasonal plankton phenology in meso- and eutrophic lakes (green line, phytoplankton; red line, zooplankton; modified PEG-model[94]), and on the ice phenology (gray bar). Black arrows denote either increasing $(\uparrow)$ or decreasing $(\downarrow)$ abundance of plankton species or groups. Blue arrows indicate changes toward earlier $(\leftarrow)$ or later dates $(\rightarrow)$ of succession events. The lower panel indicates significant correlations $(p<0.05)$ between the winter NAO index and water temperature profiles of both a shallow polymictic (brown area) and a deep dimictic lake (orange area) (modified after Gerten and Adrian 2001[32]). Note that ENSO impacts on water temperature are likely to vary in a similar manner among lake types.

ice cover) in both Lake Erken and Müggelsee induced earlier and more pronounced algal spring blooms[57,58,59], which thus were related to the NAO as well[58,72]. It is likely that the enhanced phytoplankton biomass in Heiligensee[30] and Plußsee[66] after mild winters also was associated with the NAO. 
For some lakes, NAO effects on plankton communities propagated into late spring. Specifically, the advancement in peak abundance of Daphnia and the timing of the clear-water phase in both Lake Constance[71,73] and Müggelsee[104] happened synchronously in response to the recent, positive NAO state, even though the lakes are located $\approx 700 \mathrm{~km}$ apart from each other. The suggested temperature-driven, large-scale coherence in the timing of the clear-water phase was supported by analysis of 71 Dutch and 21 central European lakes[105]. Even the timing of Daphnia population decline in summer in Lake Constance was related significantly to the NAO[71]. A further relationship between the NAO and zooplankton dynamics was reported from Esthwaite Water, where high NAO states accounted significantly for the overwintering success of E. gracilis[74]. Likewise, the above-described changes in population dynamics of single zooplankton species in Heiligensee after mild winters [55,82] probably were indirectly associated with the NAO.

El Niño events affected freshwater ecosystems in North America in several ways (Fig. 1). For instance, the extent of ice covers on the Laurentian Great Lakes is severely limited in mild winters following El Niño years[106]. As a consequence, the Great Lakes experienced one of the least extensive ice covers of the $20^{\text {th }}$ Century in the extreme El Niño years of 1997 and 1998 [107]. Overall, freeze-up and break-up dates from 62 lakes and rivers throughout the Northern Hemisphere (North America, Europe, Asia) were found to be related to the ENSO phenomenon[108].

The recent trends toward earlier break-up dates were spatially coherent in lakes across the Laurentian Shield, although coherence was highest for lakes with similar ice-off dates, and for lakes located at similar latitudes[109]. For example, the phenology of thawing was highly coherent among southern Wisconsin and south Dakotan lakes because these lakes integrated more or less the same seasonal weather. Ice-off dates in these regions advanced synchronously in El Niño years as weather conditions in the time period relevant for ice formation and break-up were strongly influenced by ENSO anomalies there. By contrast, lakes located further north were less affected by El Niño events[51]. Interannual changes in among-site coherence of ice events for lakes in North America, Finland, Russia, and Japan were smallest for ice-off dates, increased for ice-on dates, and were largest for ice duration[110]. The process of ice formation, primarily heat loss by the water mass of each site, depends on local conditions such as bathymetry distribution and water motion. On the contrary, thawing processes (primarily the energy balance of ice) are less site-dependent, leading to higher coherence of ice-off dates on a hemispheric scale[110]. Based on data from 184 study lakes located within the Northern Hemisphere, it was found that lakes with short ice duration have more variable freezing and thawing dates, and ice conditions generally were more variable in 1971-1990 as compared to 1951-1970[111].

Despite convincing evidence for synchronisation of processes among a variety of lakes exposed to the NAO or the ENSO (Fig. 1), the degree of such large-scale coherence is modulated by site-specific natural and anthropogenic factors (Table 1). Physical features such as lake morphology, depth, thermal structure, clarity, and ice conditions, are among the most relevant factors confounding spatial covariation among lakes[36,100]. Specifically, it was found that the NAO influence on water temperature profiles varied substantially among lakes in northeastern Germany according to differences in their heat-storage capacity[32] (Fig. 2, lower panel). Moreover, the phytoplankton spring bloom in Lake Constance usually establishes independently of the NAO (other than in Müggelsee and Lake Erken), because algal development is coupled to periods of low wind speed there[104,112]. In addition, the suggested NAO-driven synchronisation of the clear-water phase in Lake Constance and Müggelsee[104] is controversial. Analysis of a longer time series revealed that a warming trend in spring, not the NAO, was responsible for the earlier clear-water phase in Müggelsee[72]. This example illustrates well that climate-driven changes in ecosystem dynamics depend not only on the degree of a warming, but also on its detailed seasonal patterning[113]. 
TABLE 1

Known Factors Potentially Preventing Lake Features and Lake-Internal Processes from NAO- or ENSO-Induced Synchronisation*

\author{
Desynchronizing Factors \\ Geographic position, altitude
}

Changes in the catchment

Lake size and depth

\section{Affected Features}

- Ice duration and break-up date

- $\quad$ Lack of ice cover; primary productivity

- Chemical processes

- Water temperature

- Timing of clear-water phase

- Timing of lake mixis and phytoplankton spring bloom
Lakes [References]

- $\quad$ Alpine lakes $[37,51]$

- $\quad$ Lake Tahoe [68]

- $\quad$ English Lake District [31]; Wisconsin lakes $[99,115]$

- $\quad$ German lakes [32,72]

- $\quad$ Müggelsee [72]

- $\quad$ Lake Constance $[71,104]$

* Example sites include those considered in this review.

Another example illustrating regional differences in lake responsiveness to large-scale climate variation are Castle Lake and Lake Tahoe. In the former, extremely high or low values of annual primary productivity occurred in ENSO years while productivity in Lake Tahoe was unaffected by the ENSO[68,114]. The main reason for that asynchrony was the absence of an ice cover at Lake Tahoe (see above, "Effects on Phytoplankton and Primary Production"). Interestingly, both the NAO[58,72] and the ENSO[68] affected primary productivity in either European or North American lakes as mediated by ice conditions, yet the detailed underlying mechanisms were different (snow cover probably played a more important role at Castle Lake).

The altitude at which lakes are situated may also have a distorting effect. For instance, longer periods of ice cover in high-altitude lakes dampened NAO-driven coherence in winter water temperatures among Austrian lakes; actually, coherence was greatest in low-lying lakes with infrequent and short ice cover periods[37].

One should note that spatial coherence may also vary through time. For instance, the level of chemical coherence among Wisconsin lakes increased when the observation period was extended by years with droughts, also suggesting that climate change may alter the structure of interlake synchronies[99,115]. In the English Lake District, nitrate concentrations were much more coherent among lakes in a decade with low anthropogenic input compared to a period when more fertiliser was used on local farms[31]. These examples illustrate that the actual length of a time series under examination may decide whether existing synchronies will be detected or will remain concealed.

Long-term synchronies among lakes may also be constrained by variations in the relationship between regional climate and the NAO or the ENSO, respectively (see Box 3). Moreover, transregional coherence is likely to vary seasonally, according to seasonal differences in the strength of NAO and ENSO impacts. NAO effects on European freshwaters, for example, usually disappear some time in spring, because traceable NAO influences on regional weather are restricted to the period from December to March or April[116]. Stratified lakes with high heatstorage capacity, however, are predisposed to store the NAO signal for most of the year in the hypolimnion[32,39,40] (Fig. 2, lower panel).

Furthermore, it may make a difference whether one applies the traditional winter NAO index or monthly indices. Actually, it was found that the strong impact of the winter NAO on yeararound hypolimnetic water temperature in Stechlinsee (Germany) was not seen when using monthly NAO indices, except in case of the February index[117]. As a consequence, relevant 
Box 3 - Interactions AMONG THE NAO, THE ENSO, ANd Climate Change. The positive trend of the NAO during the recent decades coincided with the concurrent winter warming in West and North Europe[116,150]. As the warming is expected to continue in the next century[177], it is tempting to extrapolate observed NAO impacts on ecosystems into the future. However, one has to consider that the role of the NAO is a rather controversial issue in the climate change debate[178,179], especially since its origin is not yet fully understood[145]. The possible mechanisms driving the NAO are currently the subject of considerable scientific interest, and it is still in discussion whether anomalies in the Atlantic sea surface temperatures[180] or variations in the strength of the polar stratospheric vortex[181] are its prime drivers. It is currently suggested that the NAO may be locked in an intense phase in the future, which may change its influence on regional climate in a manner unknown today. The Icelandic low and the Azores high may also move northwards so that the traditional NAO index (based on stations in Iceland and Portugal) will no longer match the decisive pressure constellation[182].

Furthermore, there is evidence that the NAO has not always shown the same behaviour in historical times. The amplitude of its variation might have increased since the end of the "Little Ice Age" around 1850[147,183], and its influence on air temperature exhibited pronounced interdecadal variability even during the $20^{\text {th }}$ Century $[103,184]$.

Similarly, both the activity and the periodicity of the ENSO have varied considerably during the past century. In particular, ENSO variability was reduced in the 1920-1960 epoch, and ENSO events were unusually frequent, intense, or persistent since 1976. The extreme event of 1997 and 1998 was probably outside the range of variability of the past centuries. It remains unclear whether this warm state will continue into the future, and, if so, its implications for regional climate change are still rather uncertain[145]. Furthermore, there is ambiguity about the question whether El Niño events are influenced by global warming, especially since they affect global temperature itself[185].

Overall, the NAO and the ENSO are key determinants of regional climate change around the Northern Hemisphere, although many questions remain about their future behaviour. Rather abrupt shifts in NAO and ENSO states as have occurred recently - even may have greater consequences than a gradual increase in global mean temperatures, because ecosystems are particularly vulnerable to rapid climate change. Observed relationships between ecological variables and the NAO and ENSO are thus highly relevant contributions to the understanding of long-term ecosystem dynamics, yet they should always be interpreted in view of the historical and possible future variation of these ocean-atmosphere oscillations.

NAO-ecosystem relationships, and large-scale synchronies, might remain obscured if an inappropriate index is used. An example is provided for Lake Erken, where the timing of the phytoplankton spring peak was related significantly to the March NAO index but not to the winter index[58]. Similar differences may emerge when using different ENSO indices, but such effects are, to our knowledge, not yet documented for lakes.

To avoid such interpretation problems, one should focus on the comparative use of diverse climate indices. For example, it is recommended to filter air pressure records that are out of the 
NAO phase; a corrected index based on these filtered pressure series will better represent the actual NAO state[118]. Additionally, it may be useful to employ further zonal and meridional climate indices, which cover more of the variability in regional climate than the rather broad NAO or ENSO indices[119,120].

Overall, the extent to which processes in lakes exhibit synchrony is still poorly understood and merits further investigation. For example, it would be challenging to study whether synchronicities in physical, chemical, and biological variables even exceed the immediate sphere of influence of the NAO. Such planetary wave-scale synchronies are likely, since the NAO appears as a regional manifestation of the Arctic Oscillation[37,121]. Changes in mid-latitude lakes may therefore occur in parallel with similar ones in Arctic lakes[61]. Furthermore, the NAO demonstrates teleconnections with the ENSO, thus the interplay between both oscillations may produce combined effects on ecosystems[122,123]. Hence, there is a need for comparative studies across latitudinal and longitudinal gradients in order to regionalize our understanding of climatelake relationships and their spatio-temporal variability.

\section{PERSPECTIVES}

The studies reviewed here provide ample evidence that the ongoing process of climate warming contributes substantially to changes in thermal properties of Northern Hemispheric freshwater ecosystems. These changes in turn are likely to influence the seasonal phytoplankton and zooplankton succession.

In order to assess the probable nature of changes in a warmer future climate, model-based predictions should be further encouraged[124]. Previous projections demonstrated that thermal conditions of lakes in temperate and subpolar zones are widely consistent with the observed interdecadal trends. For example, simulations indicated that epilimnetic temperatures of lakes would generally increase, while hypolimnetic temperatures would remain unchanged or decrease due to early stratification[125,126]. Higher water temperatures and prolonged periods of thermal stratification under climate warming scenarios were also predicted in a number of studies[38,127,128,129,130,131,132]. Furthermore, shorter periods of ice cover under climate warming scenarios were simulated for a variety of lakes[131,133], and these simulations were consistent with the observed trends described above. More effort is now required to model possible biotic responses to climate warming. Previous simulation studies have already indicated that fish([25,134]), phytoplankton, and zooplankton communities[135] are likely to exhibit shifts in their spatial or temporal distribution in response to climate warming.

In addition to deterministic simulation modeling, relatively simple approaches - e.g., (multilinear) regression models based on relationships derived from long-term impact studies may be adequate to assess how key events (water temperatures, phenology of prominent events in the seasonal plankton succession, predator-prey relationships) will change, either synchronously or asynchronously, across geographical gradients and lake types. For example, future advancements in the timing of the phytoplankton spring bloom may be estimated based on robust statistical relationships with winter air temperatures (as predicted by regionalized General Circulation Models[136]) and the timing of ice break-up [53,56]. Potential differences among lake types should be captured effectively by specifying the most relevant desynchronising physical properties - such as lake size and depth, latitude and altitude, human population density of the drainage basin - as boundary conditions of such a statistical model. The models may be used, for example, to test the hypothesis that climate warming would tend to shift physical and biological patterns in northern dimictic lakes toward those that are currently characteristic for southern monomictic lakes[137]. Ideally, NAO and ENSO effects should be considered in model studies, although the role of these oscillations in the future is still rather speculative (see Box 3 ). 
To fulfill the model demands, and to allow detection of critical changes in their initial stages[8], systematic long-term monitoring of lakes should be further promoted[17]. Sampling strategies should focus on variables that are sensitive to climate change, even if their vulnerability is documented for a few sites or is known from laboratory experiments only (e.g., primary productivity and secondary productivity of single species[81]). We feel furthermore that there is an urgent need for lake monitoring in less well-observed areas such as subpolar and subtropical regions (see Fig. 1). Based on such long-term observations, comparative studies and metaanalyses will be feasible[138].

Moreover, a cross-disciplinary perspective is required. Climate-driven synchronies even exist among limnetic and marine or terrestrial environments[139], and the interplay among climate warming, the NAO, and ENSO events produces a great many direct, indirect, and integrated responses across ecosystem types[140,141]. For example, winter warming and the NAO influenced simultaneously the spring diatom bloom in both European lakes (see above) and the English Channel[142], yet wind speed rather than ice conditions determined the extent of turbulent mixing in the latter. Furthermore, the NAO-driven advancement in tree phenology[95,96], and in the breeding time of reptiles and amphibians[143] are equivalent to the above-mentioned temporal shifts in the seasonal plankton succession in lakes.

Overall, spatio-temporal modeling approaches with varying degrees of complexity will enable us to deduce the primary ways that climate influences the dynamics in freshwater ecosystems around the Earth. This knowledge is an ultimate prerequisite for lake management and adaptation strategies, which aim to mitigate detrimental climate effects in a changing world.

\section{ACKNOWLEDGEMENTS}

This study was funded by the Deutsche Forschungsgemeinschaft and the Leibniz-Institut für Gewässerökologie und Binnenfischerei. We are grateful to Norbert Walz and Christian Steinberg. The manuscript benefited from critical reading by Karl E. Havens and two anonymous reviewers.

\section{REFERENCES}

1. Reynolds, C.S. (1998) Linkages between atmospheric weather and the dynamics of limnetic phytoplankton. In Management of Lakes and Reservoirs during Global Climate Change. George, D.G., Jones, J.G., Punčochář, P., Reynolds, C.S., and Sutcliffe, D.W., Eds. NATO ASI Series 2, Vol. 42. pp. 15-38.

2. Wetzel, R.G. (2001) Limnology. $3^{\text {rd }}$ ed. Academic Press, San Diego, CA.

3. Zhang, Y. and Prepas, E.E (1996) Regulation of the dominance of planktonic diatoms and cyanobacteria in four eutrophic hardwater lakes by nutrients, water column stability, and temperature. Can. J. Fish. Aquat. Sci. 53, 621-633.

4. Bleiker, W. and Schanz, F. (1997) Light climate as the key factor controlling the spring dynamics of phytoplankton in Lake Zurich. Aquat. Sci. 59, 135-157.

5. Sommer, U. (1989) Plankton Ecology - Succession in Plankton Communities. Springer-Verlag, Berlin.

6. Scheffer, M. (1998) Ecology of Shallow Lakes. Chapman \& Hall, London.

7. Catalan, J. and Fee, E.J. (1994) Inter-annual variability in limnetic ecosystems: origin, patterns, and predictability. In Limnology Now: A Paradigm of Planetary Problems. Margalef, R., Ed. Elsevier, New York.

8. Hughes, L. (2000) Biological consequences of global warming: is the signal already apparent? Trends Ecol. Evol. 15, 56-61.

9. $\quad$ http://www.ife.ac.uk/reflect/

10. http://www.ilternet.edu/

11. $\quad$ http://www.fba.org.uk/

12. Carpenter, S.R., Fisher, S.G., Grimm, N.B., and Kitchell, J.F. (1992) Global change and freshwater ecosystems. Annu. Rev. Ecol. Syst. 23, 119-139.

13. Firth, P. and Fisher, S.G., Eds. (1992) Global Climate Change and Freshwater Ecosystems. SpringerVerlag, Berlin. 
14. Schindler, D.W., Beaty, K.G., Fee, E.J., Cruikshank, D.R., de Bruyn, E.R., Findlay, D.L., Linsey, G.A., Shearer, J.A., Stainton, M.P., and Turner, M.A. (1990) Effects of climate warming on lakes of the Central Boreal Forest. Science 250, 967-970.

15. Schindler, D.W., Bayley, S.E., Parker, B.R., Beaty, K.G., Cruikshank, D.R., Fee, E.J., Schindler, E.U., and Stainton, M. P. (1996a) The effects of climatic warming on the properties of boreal lakes and streams at the Experimental Lakes Area, nortwestern Ontario. Limnol. Oceanogr. 41, 1004-1017.

16. Melack, J.M., Dozier, J., Goldman, C.R., Greenland, D., Milner, A.M., and Naiman, R.J. (1997) Effects of climate change on inland waters of the Pacific coastal mountains and western Great Basin of North America. Hydrol. Process. 11, 971-992.

17. Schindler, D.W. (1997a) Widespread effects of climatic warming on freshwater ecosystems in North America. Hydrol. Process. 11, 1043-1067.

18. Schindler, D.W. (1997b) Sustaining aquatic ecosystems in boreal regions. Conserv. Ecol. 2, 18. URL: http://www.consecol.org/Journal/vol2/iss2/art18/.

19. Schindler, D.W. (2001) The cumulative effects of climate warming and other human stresses on Canadian freshwaters in the new millennium. Can. J. Fish. Aquat. Sci. 58, 18-29.

20. Williamson, C.E., Stemberger, R.S., Morris, D.P., Frost, T.M., and Paulsen, S.G. (1996) Ultraviolet radiation in North American lakes: attenuation estimates from DOC measurements and implications for plankton communities. Limnol. Oceanogr. 41, 1024-1034.

21. Schindler, D.W., Curtis, P.J., Parker, B., and Stainton, M.P. (1996b) Consequences of climate warming and lake acidification for UV-b penetration in North American lakes. Nature 379, 705-708.

22. Arnell, N., Bates, B., Lang, H., Magnuson, J.J., and Mulholland, P. (1996) Hydrology and freshwater ecology. In Climate Change 1995: Impacts, Adaptations and Mitigation of Climate Change - ScientificTechnical Analyses. Watson, R.T., Zinyowera, M.C., Moss, R.H., and Dokken, D.J., Eds. Cambridge University Press, Cambridge. pp. 325-364.

23. Lake, P.S., Palmer, M.A., Biro, P., Cole, J., Covich, A.P., Dahm, C., Gibert, J., Goedkopp, W., Martens, K., and Verhoeven, J. (2000) Global change and the biodiversity of freshwater ecosystems: impacts on linkages between above-sediment and sediment biota. BioScience 50, 1099-1107.

24. Glantz, M.H. (1992) Climate Variability, Climate Change and Fisheries. Cambridge University Press, Cambridge.

25. Stefan, H.G., Hondzo, M., Eaton, J.G., and McCormick, J.H. (1995) Predicted effects of global climate change on fishes in Minnesota lakes. Can. Spec. Publ. Fish. Aquat. Sci. 121, 57-72.

26. Regier, H.A., Lin, P., Ing, K.K., and Wichert, G.A. (1996) Likely responses to climate change of fish associations in the Laurentian Great Lakes Basin: concepts, methods and findings. Bor. Environ. Res. 1, 1-15.

27. Watson, R.T., Zinyowera, M.C., Moss, R.H., and Dokken, D.J., Eds. (1996) Climate Change 1995: Impacts, Adaptations and Mitigation of Climate Change - Scientific-Technical Analyses. Cambridge University Press, Cambridge.

28. Bolsenga, S. J. and Vanderploeg, H.A. (1992) Estimating photosynthetically available radiation into open and ice-covered freshwater lakes from surface characteristics: a high transmittance case study. Hydrobiologia 243/244, 95-104.

29. Reynolds, C.S. and Bellinger, E.G. (1992) Patterns of abundance and dominance of the phytoplankton of Rostherne Mere, England: evidence from an18-year data set. Aquat. Sci. 54, 10-36.

30. Adrian, R., Deneke, R., Mischke, U., Stellmacher, R., and Lederer, P. (1995) A long term study of the Heiligensee (1975-1992) - evidence for effects of climatic change on the dynamics of eutrophied lake ecosystems. Arch. Hydrobiol. 133, 315-337.

31. George, D.G., Talling, J.F., and Rigg, E. (2000) Factors influencing the temporal coherence of five lakes in the English Lake District. Freshwater Biol. 43, 449-461.

32. Gerten, D. and Adrian, R. (2001) Differences in the persistency of the North Atlantic Oscillation signal among lakes. Limnol. Oceanogr. 46, 448-455.

33. King, J.R., Shuter, B.J., and Zimmerman, A.P. (1997) The response of the thermal stratification of South Bay (Lake Huron) to climatic variability. Can. J. Fish. Aquat. Sci. 54, 1873-1882.

34. King, J.R., Shuter, B.J., and Zimmerman, A.P. (1999) Signals of climate trends and extreme events in the thermal stratification pattern of multibasin Lake Opeongo, Ontario. Can. J. Fish. Aquat. Sci. 56, 847-852.

35. Gerten, D. (2001) Changes in the Thermal Properties and the Seasonal Plankton Succession in Lakes: The Role of Climate Warming and the North Atlantic Oscillation [Ph.D.Thesis]. University of Potsdam, Germany.

36. Hobbie, J.E., Deegan, L.A., Peterson, B.J., Rastetter, E.B., Shaver, G.R., Kling, G.W., O’Brien, W.J., Terry Chapin, F.S., Miller, M.C., Kipphut, G.W., Bowden, W.B., Hershey, A.E., and McDonald, M.E. (1995) Long-term measurements at the Arctic LTER site. In Ecological Time Series. Powell, T.M. and Steele, J.H., Eds. Chapman \& Hall, London. pp. 391-409.

37. Livingstone, D.M. and Dokulil, M. (2001) Eighty years of spatially coherent Austrian lake surface water temperatures and their relationship to regional air temperature and the North Atlantic Oscillation. Limnol. Oceanogr. 46, 1220-1227. 
38. Robertson, D.M. and Ragotzkie, R.A. (1990) Changes in the thermal structure of moderate to large sized lakes in response to changes in air temperature. Aquat. Sci. 52, 360-380.

39. Livingstone, D.M. (1993) Temporal structure in the deep-water temperature of four Swiss lakes: a shortterm climatic change indicator? Verh. Int. Verein. Limnol. 25, 75-81.

40. Ambrosetti, W. and Barbanti, L. (1999) Deep water warming in lakes: an indicator of climatic change. $J$. Limnol. 58, 1-9.

41. Behrendt, H., Nixdorf, B., and Pagenkopf, W.G. (1993) Phenomenological description of polymixis and influence on oxygen budget and phosphorus release in Lake Müggelsee. Int. Rev. Ges. Hydrobiol. 78, 411421.

42. McCormick, M.J. (1990) Potential changes in thermal structure and cycle of Lake Michigan due to global warming. Trans. Am. Fish. Soc. 119, 183-194.

43. De Stasio, B.T., Jr., Hill, D.K., Kleinhans, J.M., Nibbelink, N.P., and Magnuson, J.J. (1996) Potential effects of global climate change on small north-temperate lakes: physics, fish, and plankton. Limnol. Oceanogr. 41, 1136-1149.

44. Mazumder, A. and Taylor, W.D. (1994) Thermal structure of lakes varying in size and water clarity. Limnol. Oceanogr. 39, 968-976.

45. Fee, E.J., Hecky, R.E., Kasian, S.E.M., and Cruikshank, D.R. (1996) Effects of lake size, water clarity, and climatic variability on mixing depths in Canadian Shield lakes. Limnol. Oceanogr. 41, 912-920.

46. Mazumder, A., Taylor, W.D., McQueen, D.J., and Lean, D.R.S. (1990) Effects of fish and plankton on lake temperature and mixing depth. Science 247, 312-315.

47. Perez-Fuentetaja, A.P., Dillon, P.J., Yan, N.D., and McQueen, D.J. (1999) Significance of dissolved organic carbon in the prediction of thermocline depth in small Canadian shield lakes. Aquat. Ecol. 33, 127-133. http://limnosun.limnology.wisc.edu/ webadmin/ice/LIAGpage.html/

49. Robertson, D.M., Ragotzkie, R.A., and Magnuson, J.J. (1992) Lake ice records used to detect historical and future climatic changes. Clim. Change 21, 407-427.

50. Assel, R. and Robertson, D.M. (1995) Changes in winter air temperatures near Lake Michigan during 18511993, as determined from regional lake-ice records. Limnol. Oceanogr. 40, 165-176.

51. Anderson, W.L., Robertson, D.M., and Magnuson, J.J. (1996) Evidence of recent warming and El Niñorelated variations in ice breakup of Wisconsin lakes. Limnol. Oceanogr. 41, 815-821.

52. Likens, G.E. (2000) A long-term record of ice cover for Mirror Lake, New Hampshire: effects of global warming. Verh. Int. Verein. Limnol. 27, 2765-2769.

53. Livingstone, D.M. (1999) Ice break-up on southern Lake Baikal and its relationship to local and regional air temperatures in Siberia and to the North Atlantic Oscillation. Limnol. Oceanogr. 44, 1486-1497.

54. Arai, T. (2000) The hydro-climatological significance of long-term ice records of Lake Suwa, Japan. Verh. Int. Verein. Limnol. 27, 2757-2760.

55. Palecki, M.A. and Barry, R.G. (1986) Freeze-up and break-up of lakes as an index of temperature changes during the transition seasons: a case study for Finland. J. Appl. Climatol. 25, 893-902.

56. Livingstone, D.M. (1997) Break-up dates of Alpine lakes as proxy data for local and regional mean surface air temperatures. Clim. Change 37, 407-439.

57. Adrian, R., Walz, N., Hintze, T., Hoeg, S., and Rusche, R. (1999) Effects of ice duration on the plankton succession during spring in a shallow polymictic lake. Freshwater Biol. 41, 621-632.

58. Weyhenmeyer, G., Blenckner, T., and Pettersson, K. (1999) Changes of the plankton spring outburst related to the North Atlantic Oscillation. Limnol. Oceanogr. 44, 1788-1792.

59. Adrian, R. and Hintze, T. (2000) Effects of winter air temperature on the ice phenology of the Müggelsee (Berlin, Germany). Verh. Int. Verein. Limnol. 27, 2808-2811.

60. Magnuson, J.J., Assel, R.A., Bouser, C.J., Dillon, P.J., Eaton, J.G., Evans, H.E., Fee, E.J., Hall, R.I., Mortsch, L.R., Schindler, D.W., Quinn, F.H., and Webster, K.H. (1997) Potential effects of climate changes on aquatic systems: Laurentian Great Lakes and Precambrian Shield Region. Hydrol. Process. 11, 825-872.

61. Hobbie, J.E., Peterson, B.J., Bettez, N., Deegan, L., O’Brien, W.J., Kling, G.W., Kipphut, G.W., Bowden, W.B., and Hershey, A.E. (1999) Impact of global change on the biogeochemistry and ecology of an Arctic freshwater ecosystem. Polar Res. 18, 207-214.

62. Magnuson, J.J., Robertson, D.M., Benson, B.J., Wynne, R.H., Livingstone, D.M., Arai, T., Assel, R.A., Barry, R.G., Card, V., Kuusisto, E., Granin, N.G., Prowse, T.D., Stewart, K.M., and Vuglinski, V.S. (2000) Historical trends in lake and river ice cover in the Northern Hemisphere. Science 289, 1743-1746.

63. Hecky, R.E. and Kilham, P. (1988) Nutrient limitation of phytoplankton in freshwater and marine environments: a review of recent evidence on the effects of enrichment. Limnol. Oceanogr. 33, 796-822.

64. Regier, H.A., Holmes, J.A., and Panly, D. (1990) Influence of temperature changes on aquatic ecosystems: an interpretation of empirical data. Trans. Am. Fish. Soc. 119, 374-389.

65. Adrian, R. and Deneke, R. (1996) Possible impact of warm winters on zooplankton succession in eutrophic lakes of the Atlantic European area. Freshwater Biol. 36, 757-770.

66. Müller-Navarra, D.C., Güss, S., and von Storch, H. (1997) Inter-annual variability of seasonal succession events in a temperate lake and its relation to temperature variability. Glob. Change Biol. 3, 429-438. 
67. Blenckner, T., Pettersson, K., and Padisák, J. (2002) Lake plankton as a tracer to discover climate signals. Verh. Int. Verein. Limnol. 28, in press.

68. Goldman, C.R., Jassby, A., and Powell, T. (1989) Inter-annual fluctuations in primary production: meteorological forcing at two subalpine lakes. Limnol. Oceanogr. 34, 310-323.

69. Jassby, A.D., Powell, T.M., and Goldman, C.R. (1990) Inter-annual fluctuations in primary production: direct physical effects and the trophic cascade at Castle Lake, California. Limnol. Oceanogr. 35, 10211038 .

70. Fee, E.J., Shearer, J.A., DeBruyn, E.R., and Schindler, E.U. (1992) Effects of lake size on phytoplankton photosynthesis. Can. J. Fish. Aquat. Sci. 49, 2445-2459.

71. Straile, D. (2000) Meteorological forcing of plankton dynamics in a large and deep continental European lake. Oecologia 122, 44-50.

72. Gerten, D. and Adrian, R. (2000) Climate-driven changes in spring plankton dynamics and the sensitivity of shallow polymictic lakes to the North Atlantic Oscillation. Limnol. Oceanogr. 45, 1058-1066.

73. Straile, D. and Geller, W. (1998) The response of Daphnia to changes in trophic status and weather patterns: a case study from Lake Constance. ICES J. Mar. Sci. 55, 775-782.

74. George, D.G. and Hewitt, D.P. (1999) The influence of year-to-year variations in winter weather on the dynamics of Daphnia and Eudiaptomus in Esthwaite Water, Cumbria. Funct. Ecol. 13, 45-54.

75. Benndorf, J., Kranich, K., Mehner, T., and Wagner, A. (2001) Temperature impact on the midsummer decline of Daphnia galeata: an analysis of long-term data from the biomanipulated Bautzen Reservoir (Germany). Freshwater Biol. 46, 199-211.

76. George, D.G. and Harris, G.P. (1985) The effect of climate on long-term changes in the crustacean zooplankton biomass of Lake Windermere, UK. Nature 316, 536-539.

77. George, D.G. and Taylor, A.H. (1995) UK lake plankton and the Gulf Stream. Nature 378, 139.

78. Taylor, A.H. (1995) North-south shifts of the Gulf Stream and their climatic connection with the abundance of zooplankton in the UK and its surrounding seas. ICES J. Mar. Sci. 52, 711-721.

79. Scharfe, M. (2000) Einfluß klimatischer Bedingungen auf die Entwicklung cyclopoidetr Copepoden während des Sommerzeitraums in einem hypertrophen See [Diplom thesis]. Universität Koblenz-Landau.

80. Chen, C.Y. and Folt, C.L. (1996) Consequences of fall warming for zooplankton overwintering success. Limnol. Oceanogr. 41, 1077-1086.

81. Moore, M., Folt, C.L., and Stemberger, R.S. (1996) Consequences of elevated temperatures for zooplankton assemblages in temperate lakes. Arch. Hydrobiol. 135, 289-319.

82. Adrian, R. (1997) Calanoid-cyclopoid interactions: evidence from an 11-year field study in a eutrophic lake. Freshwater Biol. 38, 315-325.

83. Vijverberg, J. (1980) Effect of temperature in laboratory studies on development and growth of Cladocera and Copepoda from Tjeukemeer, The Netherlands. Freshwater Biol. 10, 317-340.

84. Maier, G. (1989) The effect of temperature on the development times of eggs, naupliar and copepodite stages of five species of cyclopoid copepods. Hydrobiologia 184, 79-88.

85. Carpenter, S.R., Ed. (1988) Complex Interactions in Lake Communities. Springer-Verlag, Berlin.

86. Aebischer, N.J., Coulson, J.C., and Colebrook, J.M. (1990) Parallel long-term trends across four marine trophic levels and weather. Nature 347, 753-755.

87. Harrington, R., Woiwod, I., and Sparks, T.H. (1999) Climate change and trophic interactions. Trends Ecol. Evol. 14, 146-150.

88. Petchey, O.L., McPhearson, P.T., Casey, T.M., and Morin, P.J. (1999) Environmental warming alters foodweb structure and ecosystem function. Nature 402, 69-72.

89. Mysterud, A., Stenseth, N.C., Yoccoz, N.G., Langvatn, R., and Steinheim, G. (2001) Nonlinear effects of large-scale climatic variability on wild and domestic herbivores. Nature 410, 1096-1099.

90. Carpenter, S.R., Frost, T.M., Kitchell, J.F., and Kratz, T.K. (1993) Species dynamics and global environmental change: a perspective from ecosystem experiments. In Biotic Interactions and Global Change. Kareiva, P.M., Kingsolver, J.G., and Huey, R.B., Eds. Sinauer Associates,Sunderland, MA. pp. 267-279.

91. Crick, H.Q.P. and Sparks, T.H. (1999) Climate change related to egg-laying trends. Nature 399, $423-424$.

92. Chuine, I., Cambon, G., and Comtois, P. (2000) Scaling phenology from the local to the regional level: advances from species-specific phenological models. Glob. Change Biol. 6, 943-952.

93. Visser, M.E. and Holleman, L.J.M. (2001) Warmer springs disrupt the synchrony of Oak and Winter Moth phenology. Proc. R. Soc. London Ser. B 268, 289-294.

94. Sommer, U., Gliwicz, Z.M., Lampert, W., and Duncan, A. (1986) The PEG-model of seasonal succession of planktonic events in fresh waters. Arch. Hydrobiol. 106, 433-471.

95. Post, E. and Stenseth, N.C. (1999) Climatic variability, plant phenology, and northern ungulates. Ecology 80, 1322-1339.

96. Menzel, A. and Fabian, P. (1999) Growing season extended in Europe. Nature 397, 659.

97. Both, C. and Visser, M.E. (2001) Adjustment to climate change is constrained by arrival date in a longdistance migrant bird. Nature 411, 296-298. 
98. Magnuson, J.J., Benson, B.J., and Kratz, T.K. (1990a) Temporal coherence in the limnology of a suite of lakes in Wisconsin, U.S.A. Freshwater Biol. 23, 145-159.

99. Kratz, T.K., Sorrano, P.A., Baines, S.B., Benson, B.J., Magnuson, J.J., Frost, T.M., and Lathrop, R.C. (1998) Inter-annual synchronous dynamics in North temperate lakes in Wisconsin, USA. In Management of Lakes and Reservoirs during Global Climate Change. George, D.G., Jones, J.G., Punčochář, P., Reynolds, C.S., and Sutcliffe, D.W., Eds. NATO ASI Series 2, Vol. 42. pp. 273-287.

100. Baines, S.B., Webster, K.E., Kratz, T.K., Carpenter, S., and Magnuson, J.J. (2000) Synchronous behavior of temperature, calcium and chlorophyll in lakes of northern Wisconsin. Ecology 81, 815-825.

101. Benson, B.J., Lenters, J.D., Magnuson, J.J., Stubbs, M., Kratz, T.K., Dillon, P.J., Hecky, R.E., and Lathrop, R.C. (2000) Regional coherence of climatic and lake thermal variables of four lake districts in the Upper Great Lakes region of North America. Freshwater Biol. 43, 517-527.

102. Findlay, D.L., Kasian, S.E.M., Stainton, M.P., Beaty, K., and Lyng, M. (2001) Climatic influences on algal populations of boreal forest lakes in the Experimental Lakes Area. Limnol. Oceanogr. 46, 1784-1793.

103. Livingstone, D.M. (2000) Large-scale climatic forcing detected in historical observations of lake ice breakup. Verh. Int. Verein. Limnol. 27, 2775-2783.

104. Straile, D. and Adrian, R. (2000) The North Atlantic Oscillation and plankton dynamics in two European lakes - two variations on a general theme. Glob. Change Biol. 6, 663-670.

105. Scheffer, M., Straile, D., van Nes, E.H., and Hosper, H. (2001) Climate warming causes regime shifts in lake food webs. Limnol. Oceanogr. 46, 1780-1783.

106. Assel, R.A. and Rodionov, S. (1998) Atmospheric teleconnections for annual maximum ice cover on the Laurentian Great Lakes. Int. J. Climatol. 18, 425-442.

107. Assel, R.A., Janowiak, J.E., Boyce, D., O'Connors, C., Quinn, F.H., and Norton, D.C. (2000) Laurentian Great Lakes ice and weather conditions for the 1998 El Niño winter. Bull. Am. Meteorol. Soc. 81, 703-717.

108. Robertson, D.M., Wynne, R.H., and Chang, W.Y.B. (2000) Influence of El Niño on lake and river ice cover in the Northern Hemisphere from 1900 to 1995. Verh. Int. Verein. Limnol. 27, 2784-2788.

109. Wynne, R.H., Magnuson, J.J., Clayton, M.K., Lillesand, T.M., and Rodman, D.C. (1996) Determinants of temporal coherence in the satellite-derived 1987-1994 ice breakup dates of lakes on the Laurentian Shield. Limnol. Oceanogr. 41, 832-838.

110. Assel, R. and Herche, L. (2000) Coherence of long-term lake ice records. Verh. Int. Verein. Limnol. 27, 2789-2792.

111. Kratz, T.K., Hayden, B.P., Benson, B.J., and Chang, W.Y.B. (2000) Pattern in the interannual variability of lake freeze and thaw dates. Verh. Int. Verein. Limnol. 27, 2796-2799.

112. Gaedke, U., Ollinger, D., Kirner, P., and Bäuerle, E. (1998) The influence of weather conditions on the seasonal plankton development in a large and deep lake (L. Constance) III. The impact of water column stability on spring algal development. In Management of Lakes and Reservoirs during Global Climate Change. George, D.G., Jones, J.G., Punčochář, P., Reynolds, C.S., and Sutcliffe, D.W., Eds. NATO ASI Series 2, Vol. 42. pp. 71-84.

113. Adrian, R. (1998) The timing of warming - an important regulator of change in lake plankton communities. In Management of Lakes and Reservoirs during Global Climate Change. George, D.G., Jones, J.G., Punčochář, P., Reynolds, C.S., and Sutcliffe, D.W., Eds. NATO ASI Series 2, Vol. 42. pp. 205-222.

114. Strub, P.T., Powell, T., and Goldman, C.R. (1985) Climatic forcing: effects of El Niño on a small, temperate lake. Science 227, 55-57.

115. Webster, K.E., Kratz, T.K., Bowser, C.J., and Magnuson, J.J. (1996) The influence of landscape position on lake chemical responses to drought in northern Wisconsin. Limnol. Oceanogr. 41, 977-984.

116. Hurrell, J.W. (1995) Decadal trends in the North Atlantic Oscillation: regional temperatures and precipitation. Science 269, 676-679.

117. Gerten, D. and Adrian, R. (2002) Responses of lake temperatures to diverse North Atlantic Oscillation indices. Verh. Int. Verein. Limnol., in press.

118. Pozo-Vázquez, D., Esteban-Parra, M.J., Rodrigo, F.S., and Castro-Diez, Y. (2000) An analysis of the variability of the North Atlantic Oscillation in the time and the frequency domains. Int. J. Climatol. 20, 1675-1692.

119. Chen, D. (2000) A monthly circulation climatology for Sweden and its application to a winter temperature case study. Int. J. Climatol. 20, 1067-1076.

120. Slonosky, V.C., Jones, P.D., and Davies, T.D. (2000) Variability of the surface atmospheric circulation over Europe, 1774-1995. Int. J. Climatol. 20, 1875-1897.

121. Thompson, D.W.J. and Wallace, J.M. (1998) The Arctic Oscillation signature in the wintertime geopotential height and temperature fields. Geophys. Res. Lett. 25, 1297-1300.

122. Hurrell, J.W. and van Loon, H. (1997) Decadal variations in climate associated with the North Atlantic Oscillation. Clim. Change 36, 301-326.

123. Beamish, R.J., Noakes, D.J., McFarlane, G.A., Klyashtorin, L., Ivanov, V.V., and Kurashov, V. (1999) The regime concept and natural trends in the production of Pacific salmon. Can. J. Fish. Aquat. Sci. 56, 516-526.

124. Pace, M.L. (2001) Prediction and the aquatic sciences. Can. J. Fish. Aquat. Sci. 58, 63-72. 
125. Hondzo, M. and Stefan, H.G. (1993) Regional water temperature characteristics of lakes subjected to climate change. Clim. Change 24, 187-211.

126. Huttula, T., Peltonen, A., Bilaletdin, Ä., and Saura, M. (1993) The effects of climatic change on lake ice and water temperature. Aqua Fennica 22, 129-143.

127. Schertzer, W.M. and Sawchuk, A.M. (1990) Thermal structure of the Lower Great Lakes in a warm year: implications for the occurrence of hypolimnia anoxia. Trans. Am. Fish. Soc. 119, 195-209.

128. Hostetler, S.W. and Giorgi, F. (1995) Effects of a $2 \times \mathrm{CO}_{2}$ climate on two large lake systems: Pyramid Lake, Nevada, and Yellowstone Lake, Wyoming. Glob. Plan. Change 10, 43-54.

129. Elo, A., Huttula, T., Peltonen, A., and Virta, J. (1998) The effects of climate change on the temperature conditions of lakes. Bor. Environ. Res. 3, 137-150.

130. Hassan, H., Aramaki, T., Hanaki, K., Matsuo, T., and Wilby, R. (1998) Lake stratification and temperature profiles simulated using downscaled GCM output. Water Sci. Technol. 38, 217-226.

131. Stefan, H.G., Fang, X., and Hondzo, M. (1998) Simulated climate change effects on year-round water temperatures in temperate zone lakes. Clim. Change 40, 547-576.

132. Fang, X. and Stefan, H.G. (1999) Projections of climate change effects on water temperature characteristics of small lakes in the contiguous U. S. Clim. Change 42, 377-412.

133. Assel, R.A. (1991) Implications of $\mathrm{CO}_{2}$ global warming on Great Lakes ice cover. Clim. Change 18, 377395.

134. Magnuson, J.J., Meisner, J.D., and Hill, D.K. (1990b) Potential changes in the thermal habitat of Great Lakes fish after global climate warming. Trans. Am. Fish. Soc. 119, 254-264.

135. Mehner, T. (2001) Influence of spring water warming on predation rate of underyearling fish on Daphniaa deterministic simulation approach. Freshwater Biol. 45, 253-263.

136. Giorgi, F., Meehl, G., Kattenberg, A., Grassl, H., Mitchell, J., Stouffer, R., Tokiaka, T., Weaver, A., and Wigley, T. (1998) Simulation of regional climate change with Global Coupled Climate Models and regional modeling techniques. In The Regional Impacts of Climate Change - An Assessment of Vulnerability. Watson, R.T., Zinyowera, M.C., Moss, R.H., and Dokken, D.J., Eds. Cambridge University Press, Cambridge. pp. 429-437.

137. Porter, K.G., Saunders, P.A., Haberyan, K.A., Macubbin, A.E., Jacobsen, T.R., and Hodson, R.E. (1996) Annual cycle of autotrophic and heterotrophic production in a small, monomictic Piedmont lake (Lake Oglethorpe): analog for the effects of climatic warming on dimictic lakes. Limnol. Oceanogr. 41, 10411051

138. Osenberg, C.W., Sarnelle, O., Cooper, S.D., and Holt, R.D. (1999) Resolving ecological questions through meta-analysis: goals, metrics, and models. Ecology 80, 1105-1117.

139. Blenckner, T. and Hillebrand, H. (2002) North Atlantic Oscillation signatures in aquatic and terrestrial ecosystems. A meta-analysis. Glob. Change Biol. 8, in press.

140. Hauer, F.R., Baron, J.S., Campbell, D.H., Fausch, K.D., Hostetler, S.W., Leavesley, G.H., Leavitt, P.R., McKnight, D.M., and Stanford, J.A. (1997) Assessment of climate change and freshwater ecosystems of the Rocky Mountains, USA and Canada. Hydrol. Process. 11, 903-924.

141. Ottersen, G., Planque, B., Belgrano, A., Post, E., Reid, P.C., and Stenseth, N.C. (2001) Ecological effects of the North Atlantic Oscillation. Oecologia 128, 1-14.

142. Irigoien, X., Harris, R.P., Head, R.N., and Harbour, D. (2000) North Atlantic Oscillation and spring bloom phytoplankton composition in the English Channel. J. Plankton Res. 22, 2367-2371.

143. Forchhammer, M.C., Post, E., and Stenseth, N.C. (1998) Breeding phenology and climate. Nature 391, 2930 .

144. Macilwain, C. (2000) Global-warming sceptics left out in the cold. Nature 403, 233.

145. Houghton, J.T., Ding, Y., Griggs, D.J., Noguer, M., van der Linden, P.J., Dai, X., Maskell, K., and Johnson, C.A., Eds. (2001) Climate Change 2001: The Scientific Basis. Contribution of Working Group I to the Third Assessment Report of the Intergovernmental Panel on Climate Change. Cambridge University Press, Cambridge.

146. Mann, M.E., Bradley, R.S., and Hughes, M.K. (1998) Global-scale temperature patterns and climate forcing over the past six centuries. Nature 392, 779-787.

147. Pfister, C. (1999) Wetternachhersage: 500 Jahre Klimavariationen und Naturkatastrophen (1496-1995). Verlag Paul Haupt, Bern, Switzerland.

148. Hurrell, J.W., Kushnir, Y., and Visbeck, M. (2001) The North Atlantic Oscillation. Science 291, 603-605.

149. Lamb, P.J. and Peppler, R.A. (1987) North Atlantic Oscillation: concept and application. Bull. Am. Meteorol. Soc. 68, 1218-1225.

150. Hurrell, J.W. (1996) Influence of variations in extratropical wintertime teleconnections on Northern Hemisphere temperature. Geophys. Res. Lett. 23, 665-668.

151. Kapala, A., Mächel, H., and Flohn, H. (1998) Behaviour of the centres of action above the Atlantic since 1881. II. Associations with regional climate anomalies. Int. J. Climatol. 18, $23-36$.

152. Rossby, C.G. (1939) Relations between variations in the intensity of the zonal circulation and the displacements of the semipermanent centres of action. J. Mar. Res. 2, 38-55. 
153. Mächel, H., Kapala, A., and Flohn, H. (1998) Behaviour of the centres of action above the Atlantic since 1881. I. Characteristics of seasonal and inter-annual variability. Int. J. Climatol. 18, 1-22.

154. Van Loon, H. and Rogers, J.C. (1978) The seesaw in winter temperatures between Greenland and Northern Europe. I. General description. Mon. Weather Rev. 106, 296-310.

155. Stephenson, D.B., Pavan, V., and Bojariu, R. (2000) Is the North Atlantic Oscillation a Random Walk? Int. J. Climatol. 20, 1-18.

156. Rogers, J.C. (1984) The association between the North Atlantic Oscillation and the Southern Oscillation in the Northern Hemisphere. Mon. Weather Rev. 112, 1999-2015.

157. http://tao.atmos.washington.edu/data sets/nao/

158. Quinn, W.H., Neal, V.T., and de Mayolo, S.E.A. (1987) El Niño occurrences over the past four and a half centuries. J. Geophys. Res. 92, 14449-14461.

159. Philander, S.G. (1990) El Niño, La Niña, and the Southern Oscillation. Academic Press, New York.

160. Kiladis, G.N. and Dias, H.F. (1989) Global climatic anomalies associated with extremes in the Southern Oscillation. J. Climate 2, 1069-1090.

161. http://ingrid.ldeo.columbia.edu/filters/.NINO/SOURCES/.IGOSS/.nmc/.monthly/.ssta/NINO3

162. http://daac.gsfc.nasa.gov/CAMPAIGN DOCS/FTP SITE/INT DIS/readmes/soi.html/

163. Grove, H. (1998) Global impact of the 1789-93 El Niño. Nature 393, 318-319.

164. Glynn, P.W., Ed. (1990) Global Ecological Consequences of the 1982-1983 El Niño-Southern Oscillation. Elsevier Oceanography Series, Vol. 52. Elsevier, New York.

165. Bell, G.D. and Halpert, M.S. (1999) Climate assessment for (1998) Bull. Am. Meteorol. Soc. 80, S1-S48.

166. Ropelewski, C.F. and Halpert, M.S. (1986) North America precipitation and temperature patterns associated with the El Niño/Southern Oscillation (ENSO). Mon. Weather Rev. 114, 2352-2362.

167. Wolter, K., Dole, R.M., and Smith, C.A. (1999) Short-term climate extremes over the continental United States and ENSO. I. Seasonal temperatures. J. Climate 12, 3255-3272.

168. Mysak, L.A., Ingram, R.G., Wang, J., and van der Baaren, A. (1996) The anomalous sea-ice extent in Hudson Bay, Baffin Bay and the Labrador Sea during three simultaneous NAO and ENSO episodes. Atmos. Ocean. 34, 313-343.

169. Fraedrich, K. and Müller, K. (1992) Climate anomalies in Europe associated with ENSO extremes. Int. J. Climatol. 12, 25-31.

170. Davies, T.D., Viner, D., and Jones, P.D. (1998) Changes in atmospheric circulation and climate over the North Atlantic and Europe. In Management of Lakes and Reservoirs during Global Climate Change. George, D.G., Jones, J.G., Punčochář, P., Reynolds, C.S., and Sutcliffe, D.W., Eds. NATO ASI Series 2, Vol. 42. pp. 1-14.

171. Barber, R.T. and Chavez, F.P. (1983) Biological consequences of El Niño. Science 222, 1203-1210.

172. Ray, G.C., Hayden, B.P., Bulger, A.J., Jr., and McCormick-Ray, M.G. (1992) Effects of global warming on the biodiversity of coastal-marine zones. In Global Warming and Biological Diversity. Peters, R.L. and Lovejoy, T.E., Eds. Yale University Press, New Haven, CT. pp. 91-104.

173. Pearcy, W.G. and Schoener, A. (1987) Changes in the marine biota coincident with the 1982-1983 El Niño in the north-eastern subarctic Pacific Ocean. J. Geophys. Res. 92, 14417-14428.

174. Navarrete, S. and Lubchenco, J. (1993) Pacific Ocean coastal ecosystems and global climate change. In Earth System Responses to Global Change: Contrasts Between North and South America. Mooney, H.A., Ed. Academic Press, New York. pp. 189-193.

175. Molles, M.C. and Dahm, C.N. (1990) A perspective on El Niño and La Niña: global implications for stream ecology. J. Am. Benthol. Soc. 9, 68-76.

176. Sagarin, R.D., Barry, J.P., Gilman, S.E., and Baxter, C.H. (1999) Climate-related change in an intertidal community over short and long time scales. Ecol. Monogr. 69, 465-490.

177. ECSN (European Climate Support Network) (1995) Climate of Europe: Recent Variations, Present State and Future Prospects. Royal Netherlands Meteorological Institute.

178. Kerr, R.A.K. (1997) A new driver for the Atlantic's moods and Europe's weather? Science 275, 754-755.

179. Osborn, T.J., Briffa, K.R., Tett, S.F.B., Jones, P.D., and Trigo, R.M. (1999) Evaluation of the North Atlantic Oscillation as simulated by a coupled climate model. Clim. Dyn. 15, 685-702.

180. Rodwell, M.J., Rowell, D.P., and Folland, C.K. (1999) Oceanic forcing of the wintertime North Atlantic Oscillation and European climate. Nature 398, 320-323.

181. Perlwitz, J. and Graf, H.F. (1995) The statistical connection between tropospheric and stratospheric circulation of the Northern Hemisphere winter. J. Clim. 8, 2281-2295.

182. Paeth, H., Hense, A., Glowienka-Hense, R., Voss, R., and Cubasch, U. (1999) The North Atlantic Oscillation as an indicator for greenhouse-gas induced regional climate change. Clim. Dyn. 15, 953-960.

183. Langenberg, H. (2001) Oscillating opinion. Nature 408, 924-925.

184. Chen, D. and Hellström, C. (1999) The influence of the North Atlantic Oscillation on the regional temperature variability in Sweden: spatial and temporal variations. Tellus 51A, 505-516.

185. Trenberth, K.E. (1998) El Niño and global warming. J. Mar. Educ. 15, 12-18. 


\section{This article should be referenced as follows:}

Gerten, D. and Adrian, R. (2002) Effects of climate warming, North Atlantic Oscillation, and El Niño-Southern Oscillation on thermal conditions and plankton dynamics in northern hemispheric lakes. TheScientificWorldJOURNAL 2, 586-606.

\section{Handling Editor:}

Karl Havens, Principal Editor for Freshwater Systems — a domain of TheScientificWorldJOURNAL.

\section{BIOSKETCHES}

Dieter Gerten, Ph.D., is a Post-Doctoral Fellow at the Potsdam Institute for Climate Impact Research. His research interests include long-term development of limnic variables; global water balance and carbon cycling; climateecosystem interactions; hydrological modelling; and statistics and time series analysis.

Rita Adrian, Ph.D., is a Senior Scientist at the Leibniz Institute of Freshwater Ecology and Inland Fisheries. Her research interests include plankton ecology, long-term research, and climate-ecosystem relationships. 

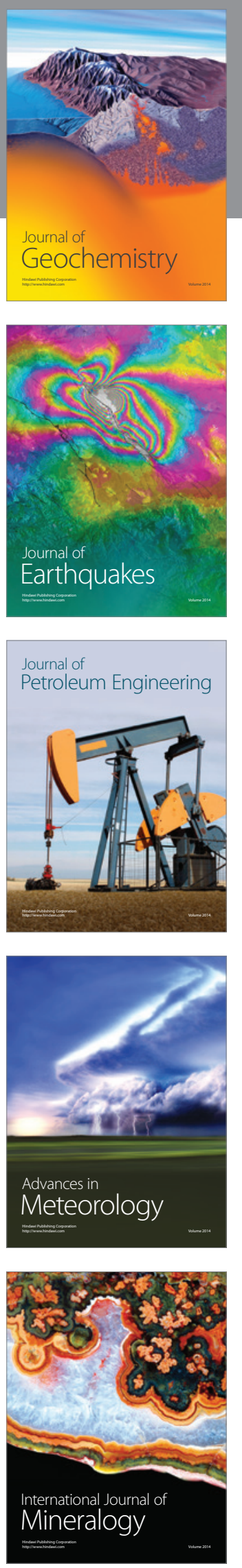
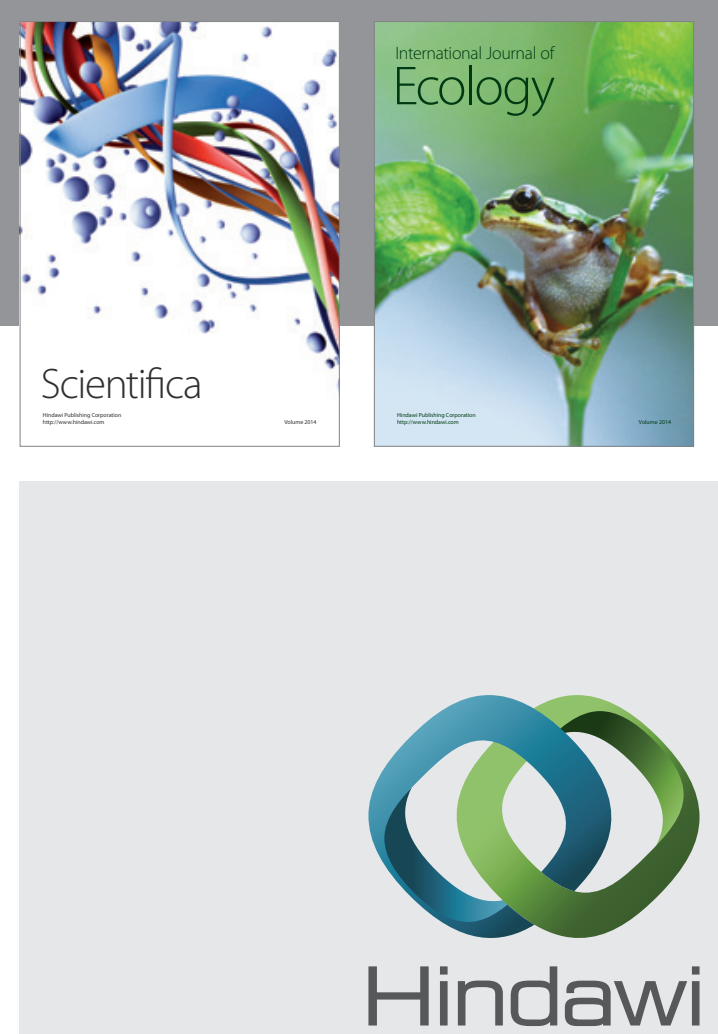

Submit your manuscripts at http://www.hindawi.com
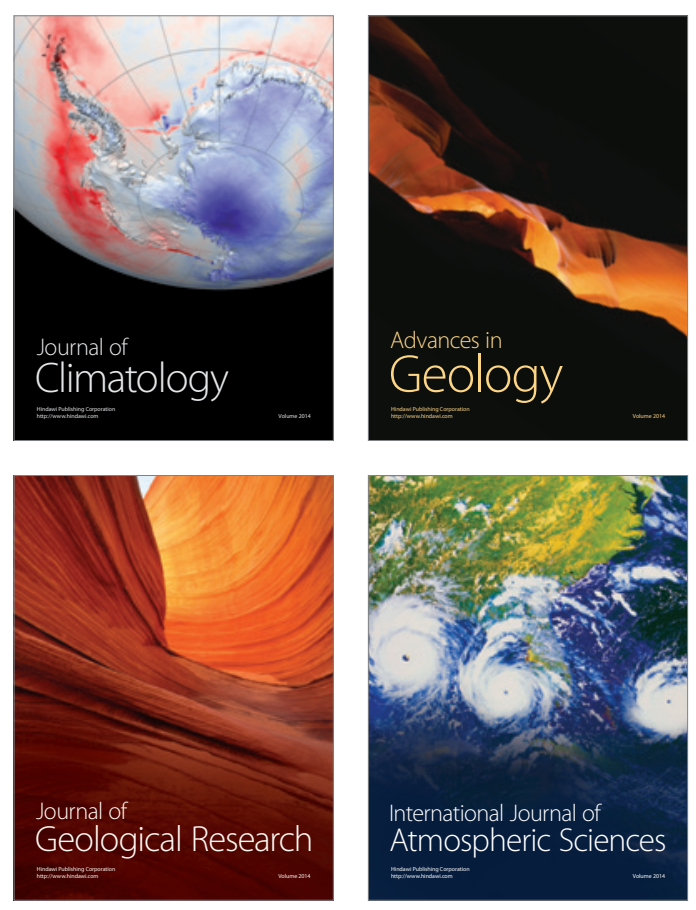
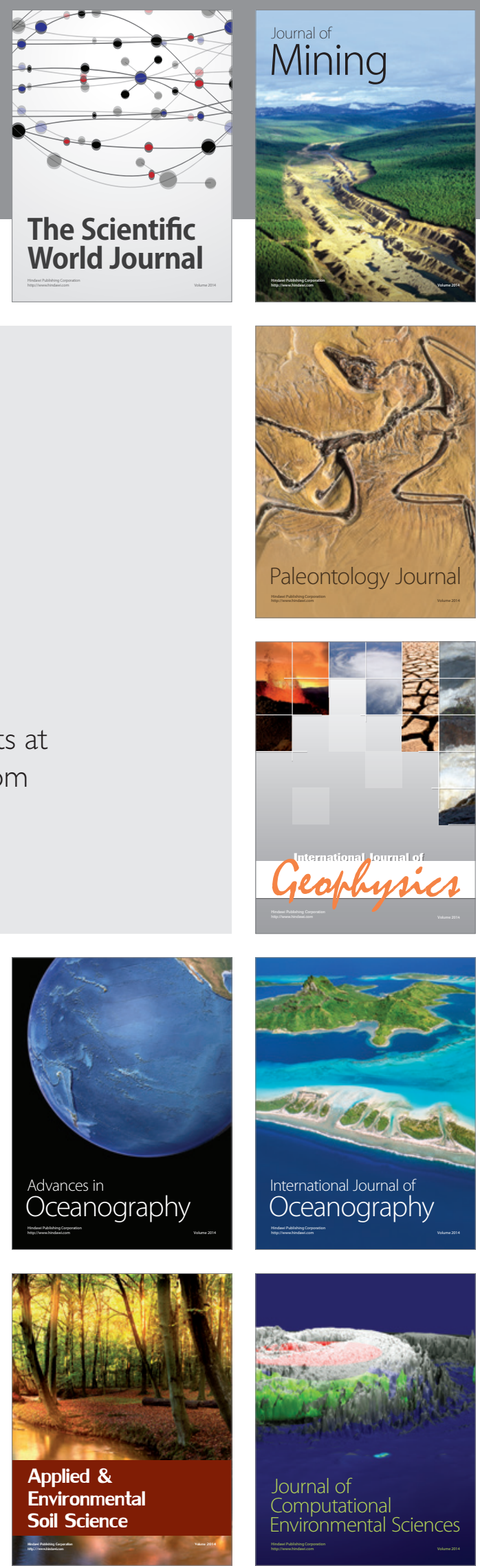